\title{
PROSPECTIVE BIOLOGICAL ACTIVE COMPOUNDS AMONG 7-SUBSTITUTED OF 3-BENZYL-8-PROPYLXANTHINES FOR TREATMENT OF METABOLIC SYNDROME PATHOLOGIES
}

\author{
Yevgen Mykhalchenko \\ Department of Biological Chemistry ${ }^{l}$ \\ ekm0989@gmail.com \\ Kateryna Aleksandrova \\ Department of Biological Chemistry ${ }^{l}$ \\ aleksandrovaev.55@gmail.com \\ Oleksandr Shkoda \\ Department of Biological Chemistry ${ }^{l}$ \\ shkodalex@gmail.com \\ Yevgen Pruglo \\ Department of Clinical Pharmacy, Pharmacotherapy and MFE of FPE \\ e.s.pruglo1986@gmail.com \\ ${ }^{1}$ Zaporizhzhia State Medical University \\ 26 Maiakovskyi ave., Zaporizhzhia, Ukraine, 69035
}

\begin{abstract}
Aim - the search for biologically active compounds with diuretic and hypoglycemic action among 7-substituted of 3-benzyl-8-propylxanthines, which can be used for the treatment of pathologies of "metabolic syndrome".

Materials and methods. 30 new chemical compounds among derivatives of 7-substituted of 3-benzyl-8-propylxanthines by PASS prediction filter were chosen for diuretic and hypoglycemic activity researches. Diuretic, hypoglycemic activity and for the most active compounds - the acute toxicity were studied in vivo. The molecular docking, which is based on EADock DSS mechanism of the modulation displayed the interaction between some of functional groups inside discovered xanthine ligands and known receptors and enzymes presented in Ligand-protein Database of Swiss Institute of Bioinformatics.

Results. It has been shown that synthesized compounds displayed strong diuretic and medium hypoglycemic activities. The molecular docking modulation (SwissDock) of interaction of xanthine derivatives hits with proposed receptors and enzymes revealed prospective of using 7-substituted of 3-benzyl-8-propylxanthines as potential drugs for treatment of metabolic syndrome pathologies.

Conclusion. The diuretic activity of the new 23 compounds of 7-substituted of 3-benzyl-8-propylxanthines and hypoglycemic activity of the new 7 derivatives of 7-substituted of 3-benzyl-8-propylxanthines was studied. Results of performed investigation illustrate that 7-substituted of 3-benzyl-8-propylxanthines demonstrate biological activity comparable to standard drugs. We also proposed probable molecular targets for the most active compounds by molecular docking method. It was shown that derivatives of 7-substituted of 3-benzyl-8-propylxanthines can be used for metabolic syndrome disorders prevention.
\end{abstract}

Keywords: metabolic syndrome, xanthines, diuretic activity, hypoglycaemic activity.

DOI: $10.21303 / 2504-5679.2019 .00988$

\section{Introduction}

The prevalence of the metabolic syndrome (MS) is the actual problem among adult population of the developed countries [1]. In general MS is associated with increasing of everyday calories intake, sedentary lifestyle, which is based on the improvement access to quality food and the progress of the technology in which human is engaged on intelligent levels of management [2].

Unfortunately, according to the WHO data [3] of post-industrial countries the frequency of MS is $10-20 \%$ among 30 years and older population, in the USA - 34\% (44\% for those who are 
older 50 years). In addition, survey of American Diabetes Association shows that current syndrome demonstrates impetuous growth of appearance between teenagers and young people [4].

Nowadays, MS includes so-called "deadly" quartet - arterial hypertension, diabetes mellitus type 2, dyslipidemia and alimentary obesity [5].

An unpleasant feature of the combination of these diseases is that each of them get worse the progression of the other, that is, a vicious circle is formed.

Therefore, the search for drugs that would affect individual links of MS, improving carbohydrate and lipid metabolism, reducing arterial pressure can be useful in treating this "disease of civilization".

The attention of scientists who are searching for biologically active substances, is attracted by the natural nitrogen-containing heterocyclic systems [6], and the xanthine derivatives [7, 8] occupy a special place in this, among which, as well as several effective non-toxic drugs.

Aim of the research. Considering the above objective, the purposeful search for biologically active compounds among 7-substituted of 3-benzyl-8-propylxanthines became an aim of our work.

\section{Materials and methods}

Derivatives of 7-substituted of 3-benzyl-8-propylxanthines were previously synthesized by our scientific team $[9,10]$.

The research was coordinated with the internal commission of Zaporizhzhia State Medical University on bioethics (ZSMU Act No. 1 of 10.01.2019).

Experiments with animals were performed in the Scientific medical-laboratory center of the Zaporizhzhia State Medical University, certified by the SEC of the Ministry of Health of Ukraine (certificate No. 039/14). During the experiment, the animals were kept in the vivarium at a temperature of $20-22{ }^{\circ} \mathrm{C}$ and $50 \%$ humidity in a well-ventilated room, under the conditions of natural dark/ light cycle with free access to food and water.

All manipulations with animals were performed out in accordance with the requirements of GLP, the recommendations of "European Union Directive 2010/63 / EU on the protection of animals used for scientific purposes" [11].

Animals were achieved from nursery of State Institute of Pharmacology and Toxicology of National Medical Academy of Ukraine.

The study of diuretic activity was performed on nonlinear rats weighing 135-288 $\mathrm{g}$ using the Berkhin method [12]. For the observation of diuretic activity was used 7 rats in each group. In the study of water diuresis, rats were kept on a constant diet with free access to water. To the water load animals were kept for two hours without food and water. Subsequently, the animals were injected into the stomach with the help of a probe of the test substance in the form of aqueous suspension at the same time as an aqueous loading in the amount of $3 \mathrm{ml}$ per $100 \mathrm{~g}$ body weight of the animal. Urine was collected every hour for 4 hours. Hydrochlorothiazide was used as reference drug.

Hypoglycemic activity (in vivo) was modelled by an oral glucose tolerance test [13], which was simulated by a load of animals at a dose of $2 \mathrm{~g} / \mathrm{kg}$ body weight. The study used nonlinear white rats weighing 128-163 g, divided into 10 groups of 7 rats in each: 1 - intact; 2 - control of glycaemia without treatment; 3-9 - with the use of the studied xanthine derivatives; 10 - with glibenclamide therapy $(5 \mathrm{mg} / \mathrm{kg})$. The blood sample was taken from the femoral vein in 30 minutes. The glucose level was measured by the glucose oxidase method.

Molecular docking experiments were performed at the SwissDock web server (http://www. swissdock.ch, this server is free for academic use) $[14,15]$.

The results of the research were processed by modern methods of the analysis on personal computer with the use of a statistical package Statistica ${ }^{\circledR}$ for Windows 6.0 license program (StatSoft Inc., License No. AXXR712 D833214FAN5). The normality of distribution of quantitative signs was analyzed by Shapiro-Wilk's test. The parameters had normal distribution. The comparison of indicators in groups was carried out with the use of Student's test. The difference on $\mathrm{p}<0.05$ was considered statistically significant. All tests were bilateral. For definition of reliable distinctions between quality indicators the non-parametric statistical criteria were used (the analysis of tables - criterion $\chi^{2}$ ). 


\section{Results}

For the enzyme DPP-4 [16], we have calculated the interaction with phenylthiosemicarbazone of 3-benzyl-8-propylxanthynyl-7 acetic acid. The classic inhibition of this enzyme is the covalent interaction with serine 630 (the major nucleophile involved in the hydrolase reaction). Molecular docking displayed possible interactions to form a hydrogen bond with threonine 304 and hydrophobic interaction with phenylalanine 208, which prevents suitable substrate to the active site nucleophile.

Molecular docking revealed the formation of three hydrophobic bindings between phenylthiosemicarbazone of 3-benzyl-8-propylxanthynyl-7 acetic acid and glycine 47, isoleucine 46 and 218 , which correlates with the inhibition data of enzyme $11 \beta$-hydroxysteroid dehydrogenase type 1 (HSD 11B1) [17].

Also, by molecular docking [18], we have found possible agonistic activity through forming hydrogen bonds between phenylthiosemicarbazone of 3-benzyl-8-propylxanthynyl-7 acetic acid and the receptor peroxisomal proliferative activating receptor gamma ( $\gamma$-PPAR).

We achieved the result of molecular docking, which indicate the presence of interactions between hydrazide 3-benzyl-8-propylxanthinyl-7 acetic acid and phenylalanine 1276, which blocks interaction of A1-receptor [19] with targeted mediator - adenosine.

Results of diuretic and hypoglycemic activities is presented in Tables $\mathbf{1 , 2 .}$

Table 1

Diuretic activity of derivatives of 3-benzyl-8-propylxanthinyl-7 acetic acid

\begin{tabular}{|c|c|c|c|}
\hline Compound & $\mathbf{X}^{*}$ & $\begin{array}{c}120 \mathrm{~min} \\
\Delta \%\end{array}$ & $\begin{array}{c}240 \mathrm{~min}, \\
\Delta \%\end{array}$ \\
\hline 1 & 2 & 3 & 4 \\
\hline Hydrochlorothiazide & & 78.79 & 73.10 \\
\hline E-71 & $-\mathrm{NH}-\mathrm{N}=\mathrm{CH}-\mathrm{C}_{6} \mathrm{H}_{5}$ & 14.42 & 42.62 \\
\hline E-104 & $-\mathrm{NH}-\mathrm{N}=\mathrm{CH}-\mathrm{p}-\mathrm{C}_{6} \mathrm{H}_{4} \mathrm{Br}$ & 70.19 & 82.51 \\
\hline E-79 & $-\mathrm{NH}-\mathrm{N}=\mathrm{CH}-\mathrm{p}-\mathrm{C}_{6} \mathrm{H}_{4} \mathrm{~F}$ & 95.19 & 81.42 \\
\hline Eтr. & $-\mathrm{NH}-\mathrm{N}=\mathrm{CH}-\mathrm{p}-\mathrm{C}_{6} \mathrm{H}_{4}-\mathrm{N}\left(\mathrm{CH}_{3}\right)_{2}$ & -20.19 & -24.04 \\
\hline E-78 & $-\mathrm{NH}-\mathrm{N}=\mathrm{CH}-\mathrm{p}-\mathrm{C}_{6} \mathrm{H}_{4} \mathrm{NO}_{2}$ & -9.62 & 13.66 \\
\hline E-121 & $-\mathrm{NH}-\mathrm{N}=\mathrm{CH}-\mathrm{m}-\mathrm{C}_{6} \mathrm{H}_{4} \mathrm{CH}_{3}$ & 2.97 & 132.57 \\
\hline E-77 & $-\mathrm{NH}-\mathrm{N}=\mathrm{CH}-\mathrm{m}-\mathrm{C}_{6} \mathrm{H}_{4} \mathrm{NO}_{2}$ & 29.70 & 26.29 \\
\hline E-122 & $-\mathrm{NH}-\mathrm{N}=\mathrm{CH}-\mathrm{O}-\mathrm{C}_{6} \mathrm{H}_{4}-\mathrm{OEt}$ & 3.96 & -5.14 \\
\hline E-125 & $-\mathrm{NH}-\mathrm{N}=\mathrm{CH}-\mathrm{O}-\mathrm{C}_{6} \mathrm{H}_{4} \mathrm{NO}_{2}$ & 60.40 & 95.43 \\
\hline E-127 & $-\mathrm{NH}-\mathrm{N}=\mathrm{CH}-\mathrm{CH}=\mathrm{CH}-\mathrm{CH}_{3}$ & 37.62 & 27.43 \\
\hline E-126 & $-\mathrm{NH}-\mathrm{N}=\mathrm{CH}-\mathrm{CH}=\mathrm{CH}-\mathrm{C}_{6} \mathrm{H}_{5}$ & -14.85 & 13.14 \\
\hline E-129 & & 81.40 & 67.20 \\
\hline E-130 & & 2.33 & 32.80 \\
\hline E-91 & & 66.28 & 34.95 \\
\hline
\end{tabular}


Continuation of Table 1

Note: * -

Table 2

Hypoglycemic activity of derivatives of hydrazide of 3-benzyl-8-propylxanthinyl-7 acetic acid

\begin{tabular}{|c|c|c|}
\hline Compound & $\mathrm{X}^{*}$ & Glucose level, \% \\
\hline 1 & 2 & 3 \\
\hline Control & & 100 \\
\hline Intact & & -35.76 \\
\hline Glibenclamide & & -45.66 \\
\hline E-168 & & -0.91 \\
\hline E-165 & & -1.24 \\
\hline E-64 & & -50.29 \\
\hline E-135 & & -11.23 \\
\hline
\end{tabular}


Continuation of Table 2

Note: * -

As it shown in the Table 1, most of the tested compounds demonstrated diuretic activity. Exception - compound E-63 with antidiuretic activity in period 2 and 4 hours, compounds E-78 and E-126 with antidiuretic manifestation in short period $(2 \mathrm{~h})$ and weak diuretic activity after $4 \mathrm{~h}$. The most active compound - E-61 (hydrazide of 3-benzyl-8-propylxanthinyl-7 acetic acid) displayed activity in 1.97 time bigger than reference drug hydrochlorothiazide (144.26 \% in comparison with $73.10 \%)$.

Table 2 data illustrate that four of investigated compounds have hypoglycemic activity, but only E-64 exceeds the value of reference drug - glibenclamide (decreasing of glucose level on $50.29 \%)$.

\section{Discussion}

The most promising mechanisms of the hypoglycemic activity is the increasing of insulin secretion. It is known that inhibition of the enzyme dipeptidyl peptidase 4 (DPP 4) [20] leads to the accumulation of incretins - Glucagon-like peptide-1 (GLP-1) [21] and glucose-dependent insulinotropic peptide (GIP) [22], that stimulate insulin release and inhibit glucagon secretion. In difference of the most commonly used drugs, such as insulin and sulfonylurea, GLP-1 therapy is associated with both weight loss and is accompanied by a lower risk of pathological hypoglycaemia, important manifestations for patients with type 2 diabetes mellitus.

In addition, it is known that cortisol is a powerful contrinsular hormone [23]. Accumulation of this glucocorticoid leads to an increase in gluconeogenesis, suppression of glucose transportation to cells, desensitization of insulin receptors, the stimulation of anabolic pathways for the deposition of energy macromolecules and increased blood pressure. In the biosynthesis of this corticosteroid hormone the crucial role is played by the enzyme - 11 $\beta$-hydroxysteroid dehydrogenase type 1 (HSD 11B1), inhibition of which can improve the stresses caused by this hormone.

Peroxisomal proliferative activating receptor gamma ( $\gamma$-PPAR) [24] is a transcriptional factor that belongs to the superfamily of nuclear receptors, is involved in the absorption and storage of 
fatty acids, glucose homeostasis, and has an anti-inflammatory effect. Synthetic g-PPAR agonists can be widely used in the treatment of dyslipidemia, hyperglycemia and their combination.

According to numerous investigations [25], diuretic drugs play an important role for the treatment of arterial hypertension. Many natural and synthetic xanthines are characterized by diuretic action, which, corresponding to the literature, is realized, due to the blocking of A1 adenosine receptors [26].

Up-to-date commonly used in silico methods, regrettably, have certain restrictions due imperfect prediction algorithms. Despite to some raw estimation of calculated results, presented investigations may been used as a possible way for the future researchesfor the prediction of the biological activity among substituted xanthines.

\section{Conclusion}

The diuretic activity of the new 23 compounds of 7-substituted of 3-benzyl-8-propylxanthines and hypoglycemic activity of the new 7 derivatives of 7-substituted of 3-benzyl-8-propylxanthines was studied. Results of performed investigation illustrate that 7-substituted of 3-benzyl8-propylxanthines demonstrate biological activity comparable to standard drugs. We also proposed probable molecular targets for the most active compounds by molecular docking method. It was shown that derivatives of 7-substituted of 3-benzyl-8-propylxanthines can be used for metabolic syndrome disorders prevention.

\section{Conflict of interest}

No conflict of interest.

\section{References}

[1] Gharipour, M., Sadeghi, M., Hosseini, M., Andalib, E., Boroujeni, M. B., Sarrafzadegan, N. (2015) Effect of age on the phenotype of metabolic syndrome in developing country. Adv Biomed Res., 4, 103.

[2] Grundy, S. M. (2016). Overnutrition, ectopic lipid and the metabolic syndrome. Journal of Investigative Medicine, 64 (6), 1082-1086. doi: http://doi.org/10.1136/jim-2016-000155

[3] Saklayen, M. G. (2018). The Global Epidemic of the Metabolic Syndrome. Current Hypertension Reports, 20 (2). doi: http:// doi.org/10.1007/s11906-018-0812-z

[4] National Diabetes Statistics Report (2017). Available at: http://dev.diabetes.org/sites/default/files/2019-06/cdc-statistics-report2017.pdf

[5] Clearfield, M., Pearce, M., Nibbe, Y., Crotty, D., Wagner, A. (2013). The "New Deadly Quartet" for Cardiovascular Disease in the 21st Century: Obesity, Metabolic Syndrome, Inflammation and Climate Change: How Does Statin Therapy Fit into this Equation? Current Atherosclerosis Reports, 16 (1). doi: http://doi.org/10.1007/s11883-013-0380-2

[6] Vitaku, E., Smith, D. T., Njardarson, J. T. (2014). Analysis of the Structural Diversity, Substitution Patterns, and Frequency of Nitrogen Heterocycles among U.S. FDA Approved Pharmaceuticals. Journal of Medicinal Chemistry, 57 (24), 10257-10274. doi: http://doi.org/10.1021/jm501100b

[7] Levich, S., Aleksandrova, K., Belenichev, I., Shkoda, A. (2013). Cerebroprotective activity of 3-benzylxanthine derivative compound Ale-15, in conditions of bilateral common carotid arteries ligation (ischemic stroke). International Journal of Basic \& Clinical Pharmacology, 2 (6), 705-710. doi: http://doi.org/10.5455/2319-2003.ijbcp20131207

[8] Aleksandrova, K. V., Belenichev, I. F., Shkoda, O. S. (2016). Influence of 3-methylxanthine derivative on the morphological and functional characteristics of neurons of sensorimotor cortex of rats with experimental intracerebral hemorrhage. Journal of cerebral blood flow and metabolism, 36, 787.

[9] Mikhal'chenko, E. K., Aleksandrova, K. V., Levich, S. V., Korzhova, A. S. (2017). Synthesis and physical-chemical properties of functional derivatives of 3-benzyl-8-propylxanthinyl-7-acetic acid. Current Issues in Pharmacy and Medicine: Science and Practice, 10 (2), 141-146. doi: http://doi.org/10.14739/2409-2932.2017.2.103521

[10] Aleksandrova, K. V., Mykhalchenko, Ye. K., Pruhlo, Ye. S., Sinchenko, D. M. (2018). Pat. No. 128510 UA. Hidrazyd 3-benzyl8-propilksantyn-7-il atsetatnoi kysloty, yakyi vyiavliaie diuretychnu diiu. MPK: S07D 473/00. No u201802221 declareted: 05.03.2018; published: 25.09.2018, Bul. No. 18

[11] Directive 2010/63/EU of the European Parliament and of the Council. (2016). Official Journal of the European Union.

[12] Berkhin, Ye. B. (1977). Metody izucheniya deistviya novykh khimicheskikh soyedineniy na funkciyu pochek. Khimikofarmatsevtychnyi zhurnal, 11 (5), 3-11. 
[13] Devi, K., Khanam, S., Rabbani, S. (2010). Protective role of glibenclamide against nicotinamide-streptozotocin induced nuclear damage in diabetic Wistar rats. Journal of Pharmacology and Pharmacotherapeutics, 1 (1), 18-23. doi: http://doi.org/ 10.4103/0976-500x.64531

[14] Grosdidier, A., Zoete, V., Michielin, O. (2011). SwissDock, a protein-small molecule docking web service based on EADock DSS. Nucleic Acids Research, 39, 270-277. doi: http://doi.org/10.1093/nar/gkr366

[15] Grosdidier, A., Zoete, V., Michielin, O. (2011). Fast docking using the CHARMM force field with EADock DSS. Journal of Computational Chemistry, 32 (10), 2149-2159. doi: http://doi.org/10.1002/jcc.21797

[16] Klei, H. E. (2013). Crystal structure of dipeptidyl-peptidase 4 (CD26, adenosine deaminase complexing protein 2) (DPPIV-WT) complex with bms-767778 AKA 2-(3-(aminomethyl)-4-(2,4- dichlorophenyl)-2-methyl-5-oxo-5,7-dihydro-6h-pyrrolo[3,4- b]pyridin-6-yl)-n,n-dimethylacetamide. doi: http://doi.org/10.2210/pdb4jh0/pdb

[17] Loenze, P., Schimanski-Breves, S., Engel, C. K. (2012). Crystal Structure of 11beta-Hydroxysteroid Dehydrogenase 1 (11b-HSD1) in Complex with Urea Inhibitor. doi: http://doi.org/10.2210/pdb3qqp/pdb

[18] Mueller, J. J., Schupp, M., Unger, T., Kintscher, U., Heinemann, U. (2011). Ligand binding domain of human ppar-gamma in complex with the agonist pioglitazone. doi: http://doi.org/10.2210/pdb2xkw/pdb

[19] Cheng, R. K. Y., Segala, E., Robertson, N., Deflorian, F., Dore, A. S., Errey, J. C. et. al. (2017). Crystal structure of stabilized A1 receptor in complex with PSB36 at 3.3A resolution. doi: http://doi.org/10.2210/pdb5n2s/pdb

[20] Kameoka, J., Tanaka, T., Nojima, Y., Schlossman, S., Morimoto, C. (1993). Direct association of adenosine deaminase with a T cell activation antigen, CD26. Science, 261 (5120), 466-469. doi: http://doi.org/10.1126/science.8101391

[21] Marathe, C. S., Rayner, C. K., Jones, K. L., Horowitz, M. (2013). Glucagon-like peptides 1 and 2 in health and disease: A review. Peptides, 44, 75-86. doi: http://doi.org/10.1016/j.peptides.2013.01.014

[22] Meier, J. J., Nauck, M. A. (2005). Glucagon-like peptide 1(GLP-1) in biology and pathology. Diabetes/Metabolism Research and Reviews, 21 (2), 91-117. doi: http://doi.org/10.1002/dmrr.538

[23] Hoehn, K., Marieb, E. N. (2010). Human Anatomy \& Physiology. San Francisco: Benjamin Cummings.

[24] Michalik, L., Auwerx, J., Berger, J. P., Chatterjee, V. K., Glass, C. K., Gonzalez, F. J. et. al. (2006). International Union of Pharmacology. LXI. Peroxisome Proliferator-Activated Receptors. Pharmacological Reviews, 58 (4), 726-741. doi: http://doi.org/ 10.1124/pr.58.4.5

[25] The ALLHAT Officers and Coordinators for the ALLHAT Collaborative Research Group. (2002). Major Outcomes in HighRisk Hypertensive Patients Randomized to Angiotensin-Converting Enzyme Inhibitor or Calcium Channel Blocker vs Diuretic: The Antihypertensive and Lipid-Lowering Treatment to Prevent Heart Attack Trial (ALLHAT). JAMA: The Journal of the American Medical Association, 288 (23), 2981-2997. doi: http://doi.org/10.1001/jama.288.23.2981

[26] Singh, N., Shreshtha, A. K., Thakur, M. S., Patra, S. (2018). Xanthine scaffold: scope and potential in drug development. Heliyon, 4 (10), e00829. doi: http://doi.org/10.1016/j.heliyon.2018.e00829

Received date 29.08.2019

Accepted date 15.09.2019

Published date 20.09.2019
(C) The Author(s) 2019

This is an open access article under the CC BY license (http://creativecommons.org/licenses/by/4.0). 